\title{
Pesquisas com células embrionárias e reprodução assistida
}

\author{
Stem cell research and assisted reproduction
}

Rui Alberto Ferriani

Temos acompanhado em tempos recentes uma grande discussão sobre a pesquisa com células-tronco, especialmente as embrionárias. O potencial de aplicação já não faz parte do futuro, e já há casos, alguns pioneiros no Brasil, de pacientes com doenças crônicas beneficiados com essas técnicas modernas. A questão tem se tornado mais polêmica quando se fala sobre a fonte das células-tronco a partir das células embrionárias. Imediatamente surge a discussão da clonagem reprodutiva, cujo desenvolvimento é condenável, opinião essa de consenso nos diversos países, apesar de haver ainda alguns raros cientistas aventureiros preconizando o uso dessa técnica. Portanto, clonagem reprodutiva não deveria afastar a discussão sobre clonagem terapêutica, essa sim de grande utilidade para a ciência atual.

O uso terapêutico das células embrionárias é tecnologia nova com grande potencial médico, particularmente na área de medicina de transplantes. Envolve a transferência do núcleo de uma célula adulta do paciente para um oócito doador enucleado com o propósito de gerar um embrião. Esse cresce até estádio de blastocisto, fase em que as células-tronco podem ser obtidas e diferenciadas em tecidos adultos. Essas células podem também ser obtidas a partir de tecidos adultos. Embora haja discussões técnicas sobre quais células seriam melhores para finalidades terapêuticas, a grande discussão ainda se refere à origem das células ${ }^{1}$. Não há praticamente objeções quanto ao uso das células adultas, mas há muitas objeções quanto ao uso dos embriões, sejam eles obtidos a partir de embriões excedentes após técnicas de reprodução assistida, sejam eles especialmente manufaturados com finalidades terapêuticas.

Tecnicamente, as células embrionárias destinadas a pesquisas com células-tronco têm capacidade de diferenciação elevada, o que as torna promissoras. Mas as discussões éticas são relevantes, e envolvem também aspectos do cotidiano de clínicas de reprodução humana, que têm dificuldades com o destino dos embriões excedentes. Aos casais em tratamento para infertilidade e que se submetem a fertilização in vitro (FIV) e transferência de embriões, são oferecidas as opções de congelamento de embriões excedentes, doação para casais inférteis, doação para pesquisa ou então não submeter todos os oócitos obtidos à fecundação, para evitar a formação de embriões supranumerários. Para casais conscientes, esse momento é de angústia. Congelar os embriões pode aumentar as chances de uma concepção futura, já que nova tentativa em caso de insucesso evitaria as complicações de hiperestimulação ovariana e nova punção folicular. Entretanto, o que fazer com esses embriões, no futuro, gera preocupações, já que o descarte não é permitido no Brasil. As clínicas ficam com esses embriões estocados, gerando responsabilidade e custos. Recentemente, contatamos vários casais que têm embriões congelados no Hospital das Clínicas de Ribeirão Preto, para tentar dar um destino a esses embriões. Encontramos casos de falecimento de um dos cônjuges, separações conjugais, desconforto por parte dos casais em relação a essa suposta "pressão" da clínica, irritação por serem contatados, demonstrando que congelar pode gerar efeitos tardios imprevisiveis, apesar dos benefícios de curto prazo.

O Brasil assumiu uma posição legal audaciosa, ao permitir o uso de embriões congelados para fins de pesquisa, de acordo com a Lei de Biossegurança promulgada em março de 2005. Essa lei não permitiu o uso de embriões a fresco, talvez para não prejudicar os casais, já que o congelamento poderia aumentar as chances de gravidez futura e a decisão após três anos de doação seria decisão mais amadurecida. Além disso, afasta a possibilidade de que se produzam embriões apenas para gerar embriões para pesquisa. Mas foi um avanço, e agora que sabemos dessa possibilidade, é preciso informar o casal já no momento do congelamento. Temos poucos dados sobre o que pensam

Professor Titular do Departamento de Ginecologia e Obstetrícia da Faculdade de Medicina de Ribeirão Preto, Universidade de São Paulo - USP - São Paulo (SP) - Brasil. 
os casais sobre esses aspectos, já que convicções morais, éticas e religiosas influenciam essas decisões. Em estudo apoiado pelo Conselho Regional de Medicina de São Paulo, em fase de publicação, pudemos avaliar as opiniões de mulheres sobre alguns dos aspectos éticos envolvendo reprodução assistida. Cerca de $24 \%$ das mulheres aceitavam doar seus embriões excedentes para fins de pesquisa, mesmo a fresco. Dado interessante foi a disponibilidade em congelar os embriões. Houve diferença significativa de opinião quando se compararam mulheres férteis $(41 \%)$ com mulheres inférteis $(23 \%)$ e, mais surpreendente, um número menor ainda aceitou o congelamento quando tinha conhecimento técnico sobre o assunto (médicas e acadêmicas de medicina de último ano, $12 \%)$. Esses dados ilustram como as situações individuais, assim como o conhecimento sobre o assunto, podem influenciar a opinião das mulheres.

O status ético e legal de um embrião humano tem sido motivo de debates em todo o mundo ${ }^{2}$. As definições legais incluem embriões como propriedades ou objetos, como pessoas ou como uma categoria única. Entretanto, talvez o fator que mais influencie uma decisão do casal seja o religioso. A atitude em face de práticas reprodutivas varia muito de acordo com as convicções religiosas. Enquanto a FIV não é aceita pelo Vaticano, que a rejeita porque separa sexo e reprodução, ela pode ser praticada por protestantes, anglicanos e outros. De acordo com critérios teológicos católicos, o embrião formado após a concepção tem status moral de um novo ser, e assim qualquer técnica iria molestar um ser humano ${ }^{3}$. No Judaismo dá-se maior valor aos embriões após os 40 dias de concepção, enquanto os ramos Sunni and Shia do Islam acreditam que a alma (condição de ser uma pessoa) ocorra em torno do quarto mês de gestação ${ }^{4}$. No Islã, os procedimentos de FIV são aceitos, embora eles possam ser feitos apenas em marido e esposa. O desenvolvimento científico trouxe novas perspectivas que as religiões não haviam previsto, e seus conceitos, como se pode ver, são teóricos, pré-definidos.

As clínicas de reprodução assistida não têm discutido profundamente a questão ética do congelamento, atendo-se mais a aspectos técnicos. O artigo de Donadio et al. ${ }^{5}$, nesse número da RBGO, traz contribuições técnicas importantes a essa discussão, ao tentar classificar um embrião clinicamente inviável para fins reprodutivos, mas não totalmente inviável para fins de pesquisa e de aplicação em clonagem terapêutica. A casuística apresentada é considerável, e a seleção dos casos analisados em que houve transferência de apenas um tipo de embrião permite conclusões sobre o prognóstico de gravidez de acordo com critérios morfológicos de avaliação embrionária. O artigo acrescenta informações que podem ajudar a decisão do casal em congelar embriões ou não, pois do ponto de vista clínico, congelá-los com baixo escore morfológico apenas cria um problema, pois seu potencial de sucesso é muito baixo, e essas informações precisam ser passadas a eles, para se evitarem potenciais conflitos de se terem embriões congelados com prognóstico reprodutivo pobre. Mas há ainda muitos pontos conflitantes em relação ao uso desses embriões de baixo prognóstico reprodutivo.

O estabelecimento de células-tronco humanas a partir de embriões supranumerários é possível a partir de embriões frescos ou congelados. A grande preferência por embriões frescos em detrimento dos congelados segue o trabalho de cientistas da Coréia do Sul, que derivaram múltiplas linhagens de células-tronco usando embriões a fresco ${ }^{6,7}$, com eficácia muito maior do que a obtida com embriões criopreservados. As taxas de sucesso em embriões cultivados até blastocisto chegam a $20 \%$. Por outro lado, em estudo recente, Sjögren et al. ${ }^{8}$ utilizaram blastocistos com qualidade morfológica variável (e portanto incluindo aqueles de baixo potencial reprodutivo) e constataram que os embriões congelados foram superiores aos embriões frescos em formar células-tronco, enfraquecendo as conclusões de Donadio et al. $^{5}$ de que não vale a pena congelar embriões de aspecto morfológico desfavorável. De fato, não são bons para serem descongelados e aproveitados para uma nova gravidez, mas seu uso em desenvolvimento de células-tronco pode ser promissor. Em sua discussão, Donadio et al. ${ }^{5}$ ponderam que o número de embriões congelados disponíveis no mundo não seria suficiente para gerar um significativo número de linhagens celulares, e advogam que o uso de embriões a fresco poderia ajudar essa produção. De fato, após a promulgação da lei de biossegurança, várias clínicas de reprodução foram abordadas por casais que desejavam doar seus embriões mesmo que sem congelamento prévio. Do ponto de vista das clínicas, essa solução é favorável, pois evita o congelamento e suas conseqüências. As decisões corretas, baseadas em evidências, necessitam ainda de mais trabalhos que melhor definam o potencial dos embriões, 
sejam a fresco sejam congelados, e nossos legisladores e dirigentes éticos precisam ficar atentos a essas necessidades, não cerceando progressos evidentes de aplicação clínica.

Os dados de Donadio et al. ${ }^{5}$ ajudam decisões éticas. Mais estudos que avaliem o potencial de viabilidade de embriões humanos são necessários, para que se tenha cada vez mais conhecimento da evolução dos embriões produzidos. Os casais podem e devem partilhar da decisão do destino desses embriões. O potencial reprodutivo pode ser diferente do potencial de geração de célulastronco, e qualquer idéia pré-concebida pode facilmente ser questionada à medida que novos dados surjam, em velocidade crescente.

\section{Referências}

1. Lisker R. Ethical and legal issues in therapeutic cloning and the study of stem cells. Arch Med Res. 2003;34(6):607-11.

2. Steinbock B. Life before birth: the moral and legal status of embryos and fetuses. New York: Oxford University Press; 1992.

3. Schenker JG. Assisted reproductive practice: religious perspectives. Reprod Biomed Online. 2005;10(3):310-9.

4. National Bioethics Advisory Commission. Ethical issues in human stem cell research. Rockville: The Commission; 1999. v. 1 [1999 May 7 Appendix E].

5. Donadio NK, Donadio N, Delestiono CO, Aoki, T. Caracterização da inviabilidade evolutiva de embriões visando doações para pesquisas de células-tronco. Rev Bras Ginecol Obstet. 2005;27(11): 667-74.

6. Nisker JA, Gore-Langton RE. Pre-implantation genetic diagnosis: a model of progress and concern. J Soc Obstet Gynaecol Can. 1995;17(3):247-62.

7. Purdy LM. Assisted reproduction. In: Kuhse H, Singer P, editors. A companion to bioethics. Oxford: Blackwell; 1998. p. 163-72.

8. Sjögren A, Hardarson T, Andersson K, Caisander G, Lundquist M, Wikland M, et al. Human blastocysts for the development of embryonic stem cells. Reprod Biomed Online. 2004;9(3):326-9. 